\title{
The development of a culturally tailored and contextually sensitive behavior change intervention for heterosexual Xhosa-speaking women in the Eastern Cape province, South Africa
}

Citation for published version (APA):

Mpondo, F. (2018). The development of a culturally tailored and contextually sensitive behavior change intervention for heterosexual Xhosa-speaking women in the Eastern Cape province, South Africa. [Doctoral Thesis, Maastricht University]. Datawyse / Universitaire Pers Maastricht. https://doi.org/10.26481/dis.20180301fm

Document status and date:

Published: 01/01/2018

DOI:

$10.26481 /$ dis.20180301fm

Document Version:

Publisher's PDF, also known as Version of record

Please check the document version of this publication:

- A submitted manuscript is the version of the article upon submission and before peer-review. There can be important differences between the submitted version and the official published version of record. People interested in the research are advised to contact the author for the final version of the publication, or visit the $\mathrm{DOI}$ to the publisher's website.

- The final author version and the galley proof are versions of the publication after peer review.

- The final published version features the final layout of the paper including the volume, issue and page numbers.

Link to publication

\footnotetext{
General rights rights.

- You may freely distribute the URL identifying the publication in the public portal. please follow below link for the End User Agreement:

www.umlib.nl/taverne-license

Take down policy

If you believe that this document breaches copyright please contact us at:

repository@maastrichtuniversity.nl

providing details and we will investigate your claim.
}

Copyright and moral rights for the publications made accessible in the public portal are retained by the authors and/or other copyright owners and it is a condition of accessing publications that users recognise and abide by the legal requirements associated with these

- Users may download and print one copy of any publication from the public portal for the purpose of private study or research.

- You may not further distribute the material or use it for any profit-making activity or commercial gain

If the publication is distributed under the terms of Article 25fa of the Dutch Copyright Act, indicated by the "Taverne" license above,

Download date: 26 Apr. 2023 


\section{Summary}

Even though the outcomes of poverty have adverse consequences on all genders and households, it is women that are extremely burdened by this problem and become vulnerable. Women become vulnerable because they assume the role of being primary caregivers and homemakers, which often means dealing with issues of structural deprivation. Further, because many women move away from the nuclear family constructions, they have to deal with issues that come with being a primary breadwinner (i.e. socio-economic burden). The socio-economic vulnerability in turn often comes with coping and psychological wellbeing issues. Furthermore, women often get exposed to risky sexual behavior and intimate partner violence because rural societies often assign women a low social status.

Chapter 1 provides a general introduction to the thesis. First rural poverty is placed into context; then the ways in which young women get burdened by living in impoverished settings are described. A justification for the research conducted for this thesis is provided, and an outline of all the studies conducted is given.

Chapter 2 describes a study conducted during the initial problem analysis phase, which provided an in-depth understanding of how deep-rooted poverty is in rural communities of the Eastern Cape province. Further, the study showed how young women who live in that context are affected physically and psychologically, to such an extent that they have to actively find ways of coping with their distress. Moreover, it emerged that a majority of the young women interviewed were beneficiaries of child and old age social grants. Also, a majority of the homes struggled with food insecurity and could not find alternative and sustainable ways of sourcing income due to many structural impediments. The findings of the study suggested a strong need for a health Programmethat would provide coping mechanisms, which would help women deal with their distresses and also help protect their psychological wellbeing.

Chapter 3 describes another component of the problem analysis phase, which focused on factors that impacted reproductive and sexual health practices of young women. Data shows that young women who are 15-24 years old remain vulnerable to HIV/AIDS due to factors such as being having early sexual debut, older sexual partners, and engaging in unprotected sex. Further, studies show that the aforementioned risky 
sexual behaviors may be linked to poor parent-child sexual health communication, especially the timing thereof. In this chapter qualitative data was used to study variation in the timing, frequency, content of parent-child sexual health communication within South African rural families. We were interested in determining whether the patterns of communication have changed over time. The findings of this study show that parent-child communication on sexual matters in rural communities continues to be lacking and is laden with cultural idioms that are not well explained. The school sexual health curriculum also fails to adequately equip adolescents to make informed decisions regarding sexual matters.

Chapter 4 presents data from a study of determinants of poor condom use selfefficacy where concepts from the self-determination theory and gender-power measures were used. Significant associations between gender equality beliefs, HIV knowledge, power balance attitudes, negative beliefs about intimate partner violence, positive growth perspective and hopeless personal perspective were found. These associations demonstrated that psychological needs derived from self-determination theory and gender-power constructs can predict condom use self-efficacy. Also, that they may be targeted as change objectives for future sexual health promotion interventions.

Chapter 5 reports on the psychosocial correlates of intimate partner violence (IPV) that are also derived from the self-determination theory (SDT) and gender-power scales. Bivariate correlation analysis and structural equation modelling (SEM) showed that autonomy and beliefs about gender equality (BGE) were strongly associated with IPV. Further, BGE was hypothesized to play a mediating role betweem autonomy, competence, relatednes and IPV. The associations suggest that women who are in relationships that allow them to make decisions along with their partners, and women who know their possibly experience less IPV. It may also be that these women experience less IPV because they choose partners who do not espouse hegemonic masculinities.

Chapter 6 describes a quantitative effect evaluation of an intervention systematically developed and implemented amongst Xhosa-speaking women of the Eastern Cape Province. The intervention was designed to increase healthy sexual behaviors and to enhance the psychological wellbeing of young women using Self- 
determination and Social-Cognitive theories. The intervention was split into four sessions, which addressed the following: empowering women on their value and strengths, self-esteem, self-evaluation, psychological health issues (e.g. life events and problems), coping mechanisms, relationships, support and intimate partner violence, safe sexual practices and condom use self-efficacy. Effects were observed on short-term outcomes for psychological health outcomes and IPV but no effects were shown, especially regarding changing the motivation of women to enact safer sexual behaviors. The study demonstrates that even though the study may have been effective in enhancing psychological health amongst young rural women, further research would need to be conducted in order to understand how risky behaviors can be changed amongst this cohort that is most at risk.

In chapter 7, the final chapter of this dissertation, all the empirical findings are synthesized and put in perspective. In sum, this thesis provides insights into the systematic development and implementation of a health promotion intervention in rural communities of South Africa. Further, the significant results of the different studies, as well as the limitations were discussed. In addition, the implications for practice and recommendations for future research were stated. 